\title{
Contiguous spaces of remembrance in identity writing: chemistry, fiction and the autobiographic question in Primo Levi's The Periodic Table
}

\author{
Catalina Botez* \\ English Department, University of Constance, Germany
}

\begin{abstract}
In this paper the author draws on Primo Levi's problematic use of biographic narrative techniques by means of a systematic and symbolic co ordination of a selection of 21 inorganic elements pertaining to Mendeleyev's periodic table. By exploring the mechanisms of remembrance and trauma in conjunction with chemistry and the necessities of testimony, the author argues that Primo Levi's collection of vignettes both reaffirms and challenges modern conceptions of autobiography. The author applies the Greek concept of techné to notions of biographic authorship, and shows how work as narrative/linguistic skill, on the one hand, and laboratory work as scientific engagement with material elements, on the other, are combined in the figure of the Holocaust survivor cum writer scientist in order to negotiate and restore human integrity. The author sustains that Levi's decade long attempts to alleviate personal trauma are conditioned by this reinstatement of human dignity through science and intellect; essentially, Levi strives to rehabilitate the concept of life itself, so damaged by the event of the Holocaust and equally central to (auto)biographic literature and the domain of chemistry.
\end{abstract}

Keywords: autobiography; memory; chemical science; Mendeleyev's periodic table; Holocaust trauma; Jewish identity; introspection; homo faber; homo narrans; homo scientificus

\section{Introducing The Periodic Table (1995) ${ }^{1}$}

Structured to cover a historic period of over 30 years, more precisely from 1935 to 1967 , The Periodic Table is Primo Levi's most intriguing work in terms of thematic composition, autobiographical conception and technological erudition. This 'subtle, teasing book' ${ }^{2}$ of filigreed finesse is also known for its engaging blend of transgressive genres, in that it encompasses mixed narrative strategies pertaining to the novel, shortstory, (auto)biography, memoir, scientific treatise and poetical myth. As a whole, it captures the author's real-life experience in Fascist Piedmont (Northern Italy), Auschwitz and postwar Italy, the story-telling perspectives shifting from that of a chemist-physicist, a student partisan, an Auschwitz inmate, a Holocaust survivor, and last, but not least, a testimonial writer. Each selected episode of life or mythological account is built around a carefully chosen inorganic element of Mendeleyev's periodic table (21 out of 108), meant to function as a symbol and interact organically with the rest. Essentially, Primo Levi makes use of fiction and historical-scientific facts combined, and takes stance as writer of a

\footnotetext{
*Email: catalina.botez@uni konstanz.de
} 
polymorphous, hybrid text in the meta-textual ruminations of his last chapter on 'Carbon'. Through his disclaimer, he lays flexible generic boundaries for his narrative, and affirms its experimental quality by first announcing what it is not:

This is not a chemical treatise: my presumption does not reach so far 'ma voix est faible, et même un peu profane'. ${ }^{3}$ Nor is it an autobiography, save in the partial and symbolic limits in which every piece of writing is autobiographical, indeed every human work; but it is in some fashion a history. It is or would have liked to be a micro history, the history of a trade and its defeats, victories and miseries, such as everyone wants to tell when he feels close to concluding the arc of his career. ${ }^{4}$

In this rough definition of his present work, Levi does not prioritise any of the overlapping genres to which his work is partially indebted. There is no superior position for science ('chemical treatise'), life writing ('autobiography') or fiction, although he does give higher profile to his trade and career as a chemist, which he prefers to regard retrospectively as 'micro-history'. ${ }^{5}$ His perspective is, I should say, both introspective and retrospective, certifying insight into his own 'history' at the micro level. On the one hand, 'micro' refers to the small-scale insightful exploration of each of the selected chemical elements and their symbolism, hinted at in the title of the respective chapters of his book. On the other hand, 'micro' may be taken to reference Levi's openly declared responsibility as a Holocaust survivor and delegated voice for the six million, on his necessary mission to spread first-hand personal testimony. His story occasionally crosses the boundary into 'counter-history', particularly when confronted with the Aryan propagandistic strategies of the Nazis, still retained by one of them in particular (the former Dr L. Müller of Auschwitz), whom Levi contacts decades after the war. At times, however, this 'microhistory' joins similar voices to create the 'macro-history' of the Jewish people, that is, the collective memory shared with both Levi's predecessors and his fellow survivors.

Thus, the epicentre of The Periodic Table is story-writing, on the one hand, and trade practice, on the other: two activities or modes of being, I argue, that lie at the core of Levi's understanding of the world and of himself. On the one hand, the theory and practice of chemical science provide the logical code (or chain of cause and effect) necessary to order chemistry facts and life writing into a coherent whole, while also instrumental in observing the interrelated nature of the material and the human world. On the other hand, chemistry is inherently linked to Levi's own experience as a Jewish lab technician in Auschwitz, his scientific knowledge permeating every detail of his camp memory, which forms the body of narrated history in this book. Both arguments support the high profile of trade attached to chemistry by Levi.

In this paper, I will situate Primo Levi's collection of vignettes within the contemporary tradition of life writing and will show how it diverges from the autobiographical canon, or Lejeune's pact, through the unique use of science as a criterion of composition, and particularly his conception of authorship as no longer unitary, but rather dispersed through several narrative voices. I will show how Levi's oeuvre resists strict categorisation in the broad realm of Holocaust testimony through his intentional, partial break from memorialistic work at the formal and thematic levels. As such, every chapter in The Periodic Table functions both independently and as an important link to the whole, while Levi's fictionalised memory and the snippets of mythological imagination stretch the testimonial boundaries of the genre even further.

Moreover, by observing the many hypostases of Levi's self, dispersed and taking up alternative voices throughout the narrative, I will regard them as located or emplaced instances of the self, by slightly adapting Elspeth Probyn's concept of 'the geography of the possible' to the survivor's case. ${ }^{6}$ I use this notion to suggest, by extrapolation from the 
feminist sphere, that the set-up of a less favourable quotidian can be reshuffled through an individual's interrogation (and recreation or redesigning) of reality, to cause a positive shift that favours the traumatised, surviving self. In other words, 'the geography of the possible' is the new configuration or emplacement of the survivor's formerly marginal self, achieved through the recuperation of human integrity, made possible in Levi's text through scientific and literary technologies.

Essentially, I will show how Levi's investigation of the topography of his self taps into man's potential to instantiate, in modern times, the classical profiles of homo scientificus/ homo faber/homo laborans (the scientist/working man), on the one hand, and those of homo narrans/homo cogitus/homo scribens (the narrating/thinking man/the writer), on the other. I will regard both categories as closely connected to the concept or work as praxis, be it the hands-on experimental work with the chemical elements, or the more abstract, creative exploration of the words' stylistic and literary potential. Additionally, I will look at Levi's profile from the larger perspective of homo ethicus via Giorgio Agamben's theory of homo sacer, that is, the victim and outsider prone to be killed at any time, but not sacrificed, and explain why this position is a problematic one. But first to The Periodic Table as illustrative of the self-gaze onto survivorship and the writing of one's own (traumatised) life.

\section{The Periodic Table and autobiography}

In the first chapter of his notorious work On Autobiography, 'The Autobiographical Pact', Philippe Lejeune analyses previous theoretical discourses on the subject and nature of authorship, and presents the reader with a modern definition of autobiography as 'retrospective prose narrative written by a real person concerning his own existence, where the focus is his individual life, in particular the story of his personality'. ${ }^{7}$ Lejeune conditions autobiography on all the above-mentioned characteristics at once: should one not be met, then the text cannot fall into this category. He specifies that those subgenres pertaining to autobiography that is, memoirs, biography, personal novels, autobiographical poems, the journal, the diary, the self-portrait or the essay cannot be listed under autobiography, since they do not equally meet all requirements stated above. ${ }^{8}$ The core of the matter, he contends, is the perfect identification of the author with the narrator and the protagonist, primarily as a matter of intention on the part of the author.

This view, however, is flawed and dated. Following his disputes with Georges Gusdorf in 1975 and challenges to the genre brought by works like Roland Barthes by Roland Barthes, Lejeune reconsidered his pact to incorporate some paradoxes of the genre and relativise its nature. He acknowledged the illusion of truthfulness as tinted by fictionality, the authorial voice as not exclusively expressed through first-person narrative, the delusion of a unitary, complete rendition of the self, the fallibility of memory, up to affirming both the possibility and impossibility of autobiography. ${ }^{9}$ Since then, under the siege of psychoanalysis, post-structuralism and feminism, the theory of autobiography shifted from fact to fiction, questioning the referentiality of language and authorship. ${ }^{10}$ Furthermore, after Derrida, one conceives of autobiography chiefly as a transgression of the so-called 'law of genre', permuted rather to a 'law of impurity'. ${ }^{11}$ Precisely this impurity resonates with Levi's mixture of genres and particularly with his conviction that science is about experimenting with impure elements, rather than imposing purity on nature. I will return to this idea and discuss it at length shortly.

It is, however, Paul de Man who takes the deconstruction of autobiography even further and states that it is not a genre at all, but 'a figure of reading, ${ }^{12}$ not exclusively 
pertaining to autobiography, but found across a broad range of other texts, too. The author of such a text reads him- or herself in them like in a mirror, and this 'specular moment' is 'a figure or a face called into being by the substitutive trope of prosopopoeia, literally, the giving of a face, or personification'. That results in autobiographies that create 'fictions or figures' rather than the targeted self-knowledge. ${ }^{13}$ The same opinion is also held by Lacan, whose ideas of mirroring, according to Shari Benstock, reflect on autobiography as revelation of 'the impossibility of its own dream: what begins in the presumption of selfknowledge ends in the creation of a fiction. ${ }^{14}$

Sigmund Freund's contribution to autobiography expands the borders of the modern disillusionment with the unitary subject even further. In his case studies published between 1894 and 1918 (on Fräulein Elizabeth von R., Dora, the Wolf Man, and the future prospects of psychoanalysis), Freud contends that the repressed, unconscious past penetrates the present 'only as repetition or intrusive memory, disrupting linearity and giving rise to a more complex temporality'. ${ }^{15}$ It is no coincidence that Freud's definition resembles the very effects of traumatic memory, as delineated later on by Shoshana Felman and Dori Laub. While Primo Levi still maintains a roughly chronological line in evoking his past, his traumatic memory manifests itself through the split authorship, disrupted rationality, and the switch in narrative voice from first person to third person (as is obvious in the mythological stories inserted between the so-called autobiographical sequences).

Lacan takes the Freudian unconscious and states that it is 'structured like a language', ${ }^{16}$ the linguistic medium being the only realm where the unconscious reveals itself as available through 'dreams, slips of the tongue or pen, witticism or symptoms' ${ }^{17}$ Which brings psychoanalysis closer to literature in its intent to create fictionality, an aspect which takes us back to Lacan and his 'mirror stage' as a reflected construct of the self, rather than a rendition of the self as it is.

Primo Levi's The Periodic Table does imply an autobiographic intent on the author's part, evinced from the start in the preoccupation with the subject's genealogy. Also, most first-person narrative sequences bring in, by and large, elements of Levi's own biography. However, the identification author narrator protagonist is only in part valid, and arguably consistent throughout the text. But if we are to focus explicitly on those elements that pertain to the autobiographical and speak for the self-referential intent in Levi's text, it is perhaps the triad memory identity discourse that we should stress. As a 'historian of himself', ${ }^{18}$ Primo Levi builds a fairly chronological and coherent life narrative beginning with his early teenage years in Turin, through to his student and partisan years, past the internment period, and on to his work as a laboratory technician in the postwar years. Each chapter builds on the previous ones, except for two mythological stories, conferring onto the narrative the 'unity and identity across time' ${ }^{19}$ that Lejeune's autobiography requires.

Thus, chemical elements like argon, iron, potassium, nickel, tin, uranium and carbon, to name just a few, provide the framework and the hermeneutic relationships necessary to bind the life stories together. The use of the periodic table itself, as critic Stephen Martin argues, 'is not coincidental, nor is it merely fortuitous. [It] is to the inorganic chemist what the dictionary is to the language scholar and the book of logarithm tables [...] to the mathematician: that is, the major tool of the trade [...] and a universal grammar of matter. ${ }^{20}$ The interconnected, often symmetrical elements are not isolated, but have a high combinatory potential, which speaks for a pre-established order, and resonates with Levi's intention to organise events.

However, Levi's text evinces an ambivalent preference for both fact and fiction. His modern understanding of memory as fictionalised or transformed experience, rather than the act of conscious re-actualisation of events as they happened, also points to a literary 
take on experience, adjacent to the autobiographical one. As he declared in an earlier memorialistic work based on his Auschwitz experience, The Drowned and the Saved: 'It is also true that a memory evoked too often, and expressed in the form of a story, tends to become fixed in a stereotype, in a form tested by experience, crystallized, perfect, adorned, which installs itself in the place of raw memory and grows at its expense. ${ }^{21}$

The Periodic Table, thus, differs from Levi's earlier testimonial works precisely through this intentional reconfiguration of first-hand memory into fictionalised memory. As Georges Gusdorf explains in 'Conditions and Limits of Autobiography': 'The passage from immediate experience to consciousness in memory, which effects a sort of repetition of that experience, also serves to modify its significance [...] The past that is recalled has lost its flesh and bone solidity, but it has won a new and more intimate relationship to the individual life. 22

In 'Argon', the first-person narrative voice traces genealogic roots back to the first newcomers to Italy from Spain and France, but the oblique style seems to undermine, rather than confirm, the truthfulness of the account, rendering it risible and fictionalised. Levi compares his ancestors to the "inert gases in the air we breathe. They carry curious Greek names of erudite derivation which mean "the New", "the Hidden", "the Inactive" and "the Alien". They $[\ldots]$ do not interfere in any chemical reaction [...] and for precisely this reason have gone undetected for centuries. ${ }^{, 23}$ But as soon as the narrator marks his family's century-long isolationism from the Gentile community of Turin, he surprisingly comes back to deconstruct this myth by inserting counter-narratives of his predecessors' actual preference for illicit communion with the habits of their adoptive society: a certain aunt shares her time between the synagogue and the Christian church on alternative weekends, while a certain uncle 'liked prosciutto so much that, faced by the temptation of a window shop, he yielded every time, sighing, cursing [... ] as if he feared my judgment or hoped for my complicity'. ${ }^{24}$

These religious manifestations are intentionally ridiculed and portrayed as harmless, essentially human and somewhat comical drives: his ancestors' quite humorous dilemmas and choices of conduct are, thus, regarded as just an arbitrary border between the Jews and Gentiles. It also brings us to the issue of binary oppositions so often raised by Primo Levi, who cautions us against conceptions of (historical) society as intrinsically rival ethnicities grouped or divided according to the 'bipartizione amico-nemico' ${ }^{25}$ Throughout history, Levi contends, such separatist approaches proved just as dangerous as the Nazis' modern strategy 'to satiate the desire for [nationalistic] synthesis' ${ }^{26}$ Thus, for Levi it is crucial that the generally human values stand as cohesive factors at the conceptual level of all his works. In The Periodic Table, these values are investigated by understanding science as a tool for life writing, and particularly by featuring man as exponent of technological work or techné, and directly responsible for his survival.

\section{Techné as autobiographical, fictional, technological work}

The term techné was first coined by Aristotle 2500 years ago. Since then, its meaning and applicability have expanded to 'everything from a philosophical concept or idea, a historical or material process, an anthropological tool or prosthesis, an ontological condition, a mode of discourse, a way of thinking to even the basic state of life itself' ${ }^{27}$ It has also been debated and investigated in relation to larger areas of knowledge such as nature, the human and animal conditions, history, science, evolution, culture and the political. Particularly in our quickly developing technological world, techné as technology compels artists, (techno-) scientists, philosophers and politicians to rethink the interaction 
between humans and their (techno-) environment, along with its impact on the definition and boundaries of the human.

In The Periodic Table, the question of techné ${ }^{28}$ is dealt with at several levels. Primo Levi engages it to restore both the concept of work, and the shattered human dignity after Auschwitz. In this sense, the scientist qua chemist's profile is employed as a modern parallel of the ancient Greek profile of homo faber: the lab technician is featured as the industrious worker and resilient individual, as survivor, who initiates scientific, hermeneutic and literary experiments in order to recreate himself. As Levi confessed in an interview with Roberto di Caro (1987): 'In my books [ . . . I see [ . . ] an immense need [ ... ] to put order back into a world of chaos, to explain to myself and the others. [...] Writing is a way of creating order. ${ }^{29}$ It is obvious, then, why Levi chose the words 'Il sistema periodico', instead of perhaps 'La tavola periodica' in the collection's title. ${ }^{30}$ As I will show, however, Levi is ambivalent about order, in that he also insists on the significance of accident, serendipity and chance to scientific research and artistic production.

On a grander scale, Levi's rationalist pragmatism is reminiscent of the values promoted in ancient Greek philosophy, particularly in the Aristotelian virtues of character and thought and his 'doctrine of the mean', ${ }^{31}$ which are best outlined in the Nicomachean Ethics. Of particular relevance to Levi's outlook on work and art are the Aristotelian virtues of 'choice and responsibility', 'self-knowledge', 'justice' and 'practical wisdom'. As Roger Crisp points out in the introduction to his translation, they are 'dispositions engendered in us through practice or habituation', ${ }^{32}$ as an exercise leading to the 'virtuous right action'. Yet this is perhaps the aspect where Levi's work ethic diverges most from Aristotle's thought, since Levi rejects the righteous outcome in all situations and declares himself an adept of the trial and error approach: 'Whether in his chemistry, his writing, or his life, Levi pursues knowledge through testing out hypotheses and probing for the limits of error., ${ }^{33}$

In The Periodic Table, man is perceived as part of the natural world and subject to constant and constructive interaction with other natural elements through technological work or techné. The man as scientist or homo scientificus bears similarities to the technician of the pen or writer of literature, that is, homo scribendus. These are two modi vivendi which Primo Levi evokes by means of his identification with both an amphibian and a centaur: 'Io sono un amfibio, un centauro. [...] Io sono diviso in due metà. Una $\grave{e}$ quella della fabrica. [...] un'altra $\grave{e}$ quella nella quale scrivo, rispondo alle interviste, lavoro sulle mie esperienze passate e presenti. Sono proprio due mezzi cervelli. ${ }^{34}$

The metaphor of the centaur illustrates, in fact, the conjunction or co-existence in humans of the two halves of the brain as modes of expression, and reiterates humanist rationalism in relation to Levi's work. In contrast to the Marxist concept of homo laborans, which portrays the working man as alienated by modern technology, and entirely conditioned by his working conditions, ${ }^{35}$ for Levi's personas, their free will, reason and creative potential are of paramount significance. Marx, however, rightly pointed out that men lose the freedom to own their lives due to the oppressive alienation caused by automated work, an observation echoing the association with forced labour as the founding principle of the Lager system.

Inherent to the camp imagery, outside of which Levi's double persona as worker and writer is unthinkable, is Giorgio Agamben's compelling doctrine of homo sacer as prototype of the outsider, the outcast deprived of rights and susceptible by law to being killed by anyone at any time, but not to sacrifice. The problem with this association, as Ernersto Laclau and Dominick LaCapra rightly signalled, is an oversimplified view of both victimhood and Nazi ideology and practice: on the one hand, the individual's isolation from the rest wrongly implies his lack of a collective identity, ${ }^{36}$ while on the 
other hand the perpetrator's profile is more complex ${ }^{37}$ than pictured in the victimising image of Muselmänner. ${ }^{38}$

While Levi never showed any conspicuous interest in philosophical theory and was, in fact, quite sceptical of its 'inconclusive metamorphoses from Plato to Augustine, from Thomas to Hegel, from Hegel to Croce', 39 his overall concern with the philosophicalethical and anthropological issues and their links to applied science, technology, art and the human condition are surely not to be overlooked. As a scientist recognised for his austere humanism ${ }^{40}$ and balanced writing style, Levi's credo was, 'to deal with problems one by one, with honesty, intelligence and humility: this is the delicate and formidable task of today's and tomorrow's technicians. ${ }^{41}$

Levi's technician embraces nature not only as an object of scientific or specialised exploration, but also as a means to understand the human experience and his condition on earth. That is to say, the narrator in Levi's text explores the instrumental and empirical aspects of his profession by applying and testing theoretical assumptions about chemical elements not only in the lab, but also outside it. In that sense, Levi's position regarding nature and practical science echoes Gaston Bachelard's concept of 'rational materialism', 42 which should be thought of, according to the analyst Mary Tiles, as 'applied rationalism' . 43 By contextualising the periodic table, Tiles explains that it represents for chemistry precisely what the Newtonian system is for physics, that is, a landmark indicative of the transition from the empirical level to the theoretical or rational stage. ${ }^{44}$

The Bachelardian concepts of 'phenomeno-technique' and 'technologically experimental science' resonate with Levi's own view on practical chemistry. As a matter of fact, techné as technological work and applied science stands at the core of Levi's writings and particularly at the heart of The Periodic Table. The genocidal overtones that applied science and chemistry, in particular, have gained after the Holocaust, along with Levi's own position as chemist cum slave labourer in the Nazi camp, increase the complexity of techné, in as far as its tainted modern connotations go. ${ }^{45}$ In the next two sections, I will analyse the stylistic and scientific aspects of techné in Levi's text, and the manner in which they comply with either the classical or the modern model of techné. Through homo scribendus and homo scientificus, Levi draws out two feasible trajectories of survival, both subscribed to his own 'geography of the possible'.

\section{Techné: work as writing or narrative skill}

The short stories that make up The Periodic Table follow a roughly linear autobiographical line, excepting the allegorical chapters 'Mercury', 'Lead', 'Sulphur', 'Titanium' and 'Carbon'. ${ }^{46}$ These create an 'extra-temporal frame of sorts around the text, the former relating the timeless human history of Levi's ancestors and the latter the equally timeless story of an atom of carbon in the cosmos' ${ }^{47}$ Thus, fictionalised memory as techné plays a crucial part, and was often dealt with by Levi in his meta-textual comments. In the preface to another collection of vignettes titled Moments of Reprieve, he tackles the shift from the testimonial to the fictional in his work:

At Auschwitz [...] I had seen and experienced [ ...] things that imperiously demanded to be told. And I had told them, I had testified [...] With the passing of the years, writing has made a space for itself alongside my professional activity and I have ended up by switching to it entirely. [...] It is possible that the distance in time has accentuated the tendency to round out the facts or heighten the colours: this tendency, or temptation, is an integral part of writing, without it one does not write stories, but rather accounts. ${ }^{48}$ 
In 'Cerium', however, Levi engages with the question of fiction writing in reference to personal memory, creativity and stylistic choices, motivated by his methodical preference for clear communication:

Alongside the liberating relief of the veteran who tells his story, I now felt in the writing a complex, intense and new pleasure [ ... ]. It was exalting to search and find, or create, the right word, that is commensurate, concise and strong; to dredge up events from my memory and describe with the greatest rigour and the least clutter. Paradoxically, my baggage of atrocious memories became a wealth, a seed; it seemed to me that, by writing, I was growing like a plant. $^{49}$

Levi's profile as a technical writer is defined by his rigorous selection of narrative material and an effort to balance silence and language, consistency and precision. If 'distilling is beautiful' in chemistry, linguistic essentiality is central to Levi's perception of techné cum poiesis. The bridging aspect between the two is signalled, in fact, by the critic Pierpaolo Antonello: 'Various elements are shared between the two trades of technology and narrative: a need for symmetry, economy, the form fitting the purpose, careful planning and, crucially, a method of trial and error., 50

Writing for Levi is also an exercise in irony, as it is a skill in perfecting the previously mentioned Lacanian self-mirroring or gazing within. In the third chapter, 'Zinc', he re-engages the satirical slant from 'Argon' to reminisce about his pre-war naivety regarding his Jewish 'otherness'. Forcefully brought to an awareness of his 'impure' quality, he makes an analogy between his Jewish origin and 'the impurity that makes the zinc react'. Back during the pre-war years, his Jewishness was to him 'an almost negligible but curious fact, a small amusing anomaly [... ]: a Jew is somebody who at Christmas does not have a tree, who should not eat salami but eats it all the time, who has learnt a bit of Hebrew at thirteen and then has forgotten it. ${ }^{51}$ Later, though, things change: Fascism 'posits itself as the discourse of absolute truth', causing this 'accident of birth' to be 'no longer inconsequential'. ${ }^{52}$ Thus, Levi voices his abhorrence of the politicised Aryan discourse that trumpets racial purity and national homogeny, ${ }^{53}$ and does that subversively through his veiled narrative of dissent. It is, in fact, a linguistic strike, performed through an overly abundant style meant to make a strong derisive case against the nonsensical Fascist parlance:

[...] the rejection was mutual. The [Jewish] minority erected a symmetrical barrier against all of Christianity (goyim, narelim, 'Gentiles', 'the uncircumcised'), reproducing on a provincial scale and against a pacifically bucolic background the epic and Biblical situation of the chosen people. This fundamental dislocation fed the good natured wit of our uncles (barbe in the dialect of Piedmont) and our aunts (magne, also in the dialect): wise, tobacco smelling patriarchs and domestic household queens, who would still proudly describe themselves as 'the people of Israel' [...] And then in the case of the uncles and aunts who reach an extremely old age (a frequent event: we are a long lived people, since the time of Noah), the attribute barba ('uncle'), or, respectively, magna ('aunt') tends gradually to merge with the name, and, with the occurrence of diminutives and an unsuspected phonetic analogy between Hebrew and the Piedmontese dialect, become fixed in complex, strange sounding appellations [...] Thus came into existence Barbaioto (uncle Elijah), Barbasachin (Uncle Isaac), Magnaieta (aunt Maria), Barbamoisin (uncle Moses). ${ }^{54}$

This excerpt is nothing but the protest of techné as linguistic-narrative skill against the Nazi aberration through what Baxter calls Levi's attempts to 'mobilise, babelise, and bastardise the language that discriminated against him on the grounds of alterity'. ${ }^{55}$ The narrative artistry exploits (with notable stylistic effects) the linguistic potential for caricature and mockery, as antidote for the politicised, oppressive language of discrimination.

Further on, the chapter on 'Cerium' employs the accretive strategies of repetition, rewriting and retelling in order to suggest the protean nature of human identity: 
I was a chemist in a chemical plant, in a chemical laboratory (this too has to be narrated), and I stole in order to eat $[\ldots]$ and at a certain point I realized $[\ldots]$ that I was reliving me, a respectable little university graduate the involution evolution of a famous respectable dog, a Victorian, Darwinian dog who is deported and becomes a thief in order to live [...] I stole like him and like foxes: at every favourable opportunity but with sly cunning and without exposing myself. ${ }^{56}$

This essential episode in The Periodic Table, and the only one dealing directly with Levi's deportation to Auschwitz, reveals the shameful secret of his survival. Its central position within the collection of short stories, with 10 chapters preceding it and another 10 following it, also points to its relevance to Levi's life ${ }^{57}$ Its more composed, detached style marks the narrative distance to his memoir If This Is a Man (published three decades earlier), which Levi dedicated to the extensive story of his survival from Auschwitz:

At a distance of thirty years I find it difficult to reconstruct the sort of human being that corresponded, in November 1944, to the name or, better said, to my number 175517. I must have by then overcome the most terrible crisis, the crisis of having become part of the Lager system and I must have developed a strange callousness if I then managed not only to survive, but also to think, to register the world around me, and even to perform rather delicate work, in an environment infected by the daily presence of death [...] Desperation and hope alternated at a rate that would have destroyed almost any normal person in an hour. ${ }^{58}$

As I noted elsewhere, 'this profound psychological mutation, impossible to fully grasp without a first-hand experience of the Shoah, reinforces the idea that man, like matter, changes under the influence of his environment: just as the chemical elements metamorphose under pressure, due to modified physical conditions or through combination with other elements, so the human character becomes transfigured under persecution and the assault of trauma. ${ }^{59}$

\section{Techné: the chemical technician/craftman's work}

The image of the chemist as homo faber ${ }^{60}$ or tool maker/tool worker permeates Levi's work. His 'technician' is always closely engaged with nature in the shape of stones, wood, metal or basic chemical substances. Since he performs a pre-mechanised trade, Levi gives preference to a pre-modern human relationship to nature and craft, thus opposing the Aristotelian idealist disaffiliation of the human/cultural from the natural. 'As a technician, Levi rejoices in the act of breaking the matter's passive resistance. ${ }^{61}$ As Levi contends, matter is also 'the Spirit's great antagonist' ${ }^{62}$, as well as 'our hostile mother'63 simultaneously enabling and hampering learning. Therefore, the scientist's clash with this grand force is equally empowering and ennobling, in that it bestows on man the privilege to search, understand and theorise the natural world to his practical advantage:

The nobility of Man, acquired in a hundred centuries of trial and error, lay in making himself the conqueror of matter $[\ldots]$ conquering matter is to understand it, and understanding matter is necessary to understanding the universe and ourselves: and $[\ldots]$ therefore Mendeleev's Periodic Table $[\ldots]$ was poetry, loftier and more solemn than all the poetry. ${ }^{64}$

Beyond that, operational science offers Levi an 'antidote to Fascism', because its methods are 'clear and distinct and verifiable at every step, and not a tissue of lies and emptiness'. ${ }^{65}$ That is, shameful, lie-spreading propaganda is parried by the verifiable truth that techno-science is founded on. In chemistry, truth is reached through trial and error and constant assessment of the elements in their environment, which is why science is determined by serendipity, lateral thinking and intuitive decision making alike. ${ }^{66}$ Thus, to think technicity without hazard is unimaginable, because hazard is at the core of production and progress; fortuity also helps build professional experience, since error is also 'a vessel of ethical Bildung' ${ }^{67}$ Therefore, it's no wonder that the freedom to make 
mistakes differentiates the work in the factory from the work in the Lager, where even the tiniest failure or breaking of the rigid camp laws spelt death for the unfortunate. To extend the parallel, in chemistry, the scientific rules apply to all elements, whereas in the Lager, the discriminatory laws crush human dignity: the "failure to follow orders, failure to understand orders, failure to work beyond physical collapse, the error of assuming any identity or the barest human rights' can lead to swift execution at Buna-Monowitz. ${ }^{68}$ Thus, freedom could only be found in death, and not in work, as the Nazis derisively wrote in 'a horrifying parody of work' over the Auschwitz gate of Auschwitz: 'Arbeit macht frei. ${ }^{69}$ Philip Roth dwells on further issues related to work under the Nazis in an interview with Levi, tackling the role of writing in cleansing the concept of work, so tainted by the Shoah. To what extent does narrative help restore humanity and the 'disfigured' perception on Arbeit? Levi gives a surprising answer: even though the camp was undignified and dehumanising, the inmates were paradoxically motivated to do their work properly ('lavoro ben fatto'), primarily out of an incentive to retain their dignity:

I am fully aware that after the camp [...] my two kinds of work (chemistry and writing) did play $[\ldots]$ an essential role in my life. [...] Human beings are biologically built for an activity that is aimed towards a goal and [...] idleness, or aimless work (like Auschwitz's Arbeit) gives rise to suffering and to atrophy. In my case, work is identical to 'problem solving' ${ }^{70}$

Levi's answer and his choice of working as a chemist in a paint factory after the war, while simultaneously writing about the camp and his professional experience, prove that work could have sorted out for Levi the very dilemma of survival after Auschwitz, as well as the difficulties of coping with a damaged memory. That, at least, until his death in 1987, which some maintain was suicide.

In 'Cerium', the chemical element that saved his life, Levi retells the story of his survival, which contains nothing heroic, on the contrary. In order to live, he stole cerium and secretly scraped cigarette lighters out of it at night-time with his friend Alberto. ${ }^{71}$ Cerium, like all other elements, has its own identity, and is therefore depicted with equal reverence and sense of wonder as every other substance:

There was a mysterious jar on one of the shelves. It contained about twenty gray, hard, colourless, tasteless little rods and did not have a label [...] an element about which I knew nothing, save for that single practical application, and that it belongs to the equivocal and heretical rare earth group family, and that its name ... celebrates (great modesty on the chemists of past time!) the asteroid Ceres, since the metal and the star were discovered in the same year, 1801; and this was perhaps an affectionate ironic homage to alchemical couplings: just as the sun was gold and Mars iron, so Ceres must be cerium. ${ }^{72}$

To hone flints for the mere act of survival is to regress to the Stone Age and the Darwinian age of 'survival of the fittest'. At the same time, the flint as metaphor of techné is a prosthesis, that is, it bears 'tertiary', 'epiphylogenetic memory' in Stiegler's jargon; in other words, the memory of primeval survival is relived, reiterated in the camps through a paradoxical reversal of values: to return to origins means to ritualistically escape death, while regress stands for progress, that is, the promotion of the human species. In the Lager, on the other hand, the fit and the ruthless outlived the guiltless, rendering the Aristotelian code of virtues, on the one hand, and the Machiavellian concepts of 'Virtù' and 'fortuna', on the other, completely useless. 'The logic and scale of cause and effect are all skewed, chance determined life and death with a force overwhelmingly beyond the capacity (or virtù) of individuals to try out means to circumvent it. ${ }^{73}$ No wonder then that chance alone stands at the heart of Alberto's fate, ${ }^{74}$ who, although immune to scarlet fever, and technically fit to live, dies in Auschwitz due to the illogical 'piccole cose', ${ }^{75}$ while Levi gets ill, but eventually survives. 
Levi had already raised the problematic of death and evil as related to genocide in The Drowned and the Saved, where he remarked on the excessive nature of Nazi violence, often exerted as a means in itself or entirely disproportionate to its aim. When genocide becomes Telos, the driving force of the Nazis can only be explained, claims Terry Eagleton, through the unconscious fear of their own death: the abhorred Jewish otherness is for them the impersonation of non-being and a constant reminder of their own frail mortality. Consequently, mass murder is a repetitive act of reclaiming their existence and correcting 'an insidious deficiency of being', and thereby also a form of exertion and reassertion of power over their own vulnerability: 'The non-being at the core of one's identity is, among other things, a foretaste of death; and one way of fending off the terror of human mortality is to liquidate those who incarnate this trauma in their own person. ${ }^{.76}$ This bold idea inspired by Freudian psychoanalysis proposes a rethinking of victimhood as fear embodied in the perpetrators' psyche, thus shifting the perspective on anti-Semitism from hate directed towards an outsider to internalised self-loathing. But since the fear of death resurfaced in the Nazis' 'horror of impurity' is a self-feeding, ever-growing type of fear, it made sense, within this mind frame, to perfect and extend the plan to the total eradication of Jewishness, a solution particularly embraced for its 'aesthetic perfection' ${ }^{77}$ Perfection, though, as shown above, stands in stark contrast to Levi's almost programmatic preference for and exploration of the natural imperfection of elements.

Even though most chemical elements are inherently connected to some vital physiological function in humans, plants or animals, it is carbon that is considered the element (and epitome) of life. It comes as no surprise then that Levi concludes his (autobiographic) journey through the periodic table with 'Carbon', or the story of his 'old debt' to life. ${ }^{78}$ Time and again, echoing Bachelard, Levi challenges the Aristotelian duality form-matter in his depiction of carbon. According to Antonello, 'matter is not an undefined substance shaped by abstract forms superimposed from outside. It is rather a multifold entity, that displays an infinite array of behaviour and features according not to given "form", but to given "combination."79 Of which carbon, is no exception: "Carbon dioxide [ ... ] is not one of the principal components of air, but rather a ridiculous remnant, an "impurity", thirty times less abundant than argon, which nobody even notices. ${ }^{, 80}$ Yet again, and in risible contrast to the Nazi disdain for impurity, an impure element proves crucial for the creation and perpetuation of life. As Levi persuaded us before, impurities are essential catalysts for chemical interactions and often contribute to the advancement of knowledge. So, metaphorically speaking, carbon dioxide is the essential other in the process of chemical contamination, indispensable for life.$^{81}$ As I have shown elsewhere, "not only does Levi warn his reader against the danger of the discriminatory gesture, but he is also an inexhaustible supporter of the holistic view on chemistry. ${ }^{82}$ That is to say, rational judgment is often buttressed by the keenness of 'smell and touch and the intuitiveness of the eye', always supported by qualities like 'humility, patience, method, manual dexterity, nervous and muscular stamina, [and] resilience in the face of failure'. ${ }^{83}$

As performing instruments that one cannot do without, the hands are the embodiment of techné. They stand for man's ability to work and his dignity and autonomy ${ }^{84}$ Last but not least, the hand as essential tool for conducting the chemist's experiments and holding the writer's pen is both 'artifice' (or technical support of scientific work), and aid in the production of the written, literary text.

\section{Conclusion}

The Periodic Table is Primo Levi's unique and intriguing work of introspective and retrospective meditation on a wide range of topics ranging from Holocaust survivorship 
and memory preservation, to the scientist and writer's work as instances of technological testimony, to recovered integrity, rescued humanity, and last but not least, to the ethics of techno-science in pre- and post-Holocaust Europe.

As I have shown, it is also an autobiographical work in intention and certain aspects of execution, with the stress falling on the survivor's profile as a chemical technician and writer of literature, two hypostases of the 'geography of the possible', as envisaged by Levi. The central figure, previously engulfed by the enormous shadow of the Holocaust, assesses now, with lucidity and measurement, his chances to recover human and professional integrity through work, which is regarded as a counteractive principle to the Nazi concept of punishment and forced labour.

Pertaining to the mixed genre of memoir, fiction, autobiography and chemical treatise, The Periodic Table offers a generous exegetic spectrum that includes, as I demonstrated above, its examination based on the Greek concept of techné. In the current analysis, I focused on techné as the art-and-craft approach to science and writing from ancient to modern times. Thus, the short-stories focus on 21 inorganic elements of Mendeleyev's periodic table, by engaging with representations of man as both homo faber (man at work) and homo scribendus (creative man/man who writes), occasionally calling in interpretations of homo sacer (Giorgio Agamben), homo laborans (Marx) and homo ethicus. The common denominator of all these hypostases of the working man is rooted in an understanding of genocide survival as a chance to restore humanity to man through integrity and honest, productive work.

Even though Levi does not show an exclusive interest in philosophy, his general concern involves an indirect preoccupation with Aristotelian dualities like episteme versus techné, or abstract thought versus practical performance. Levi sees work in terms of Bachelard's rational materialism and the Heideggerian understanding of techné as poiesis, while Aristotle offers him the classical model of ethical thinking based on concepts like (practical) wisdom, freedom of choice and responsibility.

All in all, Primo Levi is a compelling, lucid writer preoccupied with the nature of postcatastrophic humanity. The message passed on to his reader concerns a holistic understanding of man as constitutive link in the far greater natural, cultural, social and political environment, and a strong belief in his capacity for recovery in the face of historical trauma.

\section{Notes}

1. The Italian title, as published in 1975, is $I l$ sistema periodico. The English translation bearing the title The Periodic Table appeared later in 1995.

2. Angier, The Double Bond, 12.

3. 'My voice is weak, and also a bit profane' (author's translation). This quote originates in the second verse of the Premier Chant ('first song') of Voltaire's 'La Pucelle d'Orléans', a poetic work on Joan of Arc. In this verse, as a display of humility, Voltaire seeks the reader's forgiveness for daring to sing about Joan of Arc. The reason why Levi quotes Voltaire is, in my opinion, to reinforce the scientist's humble position with regard to nature and its complex workings, well aware as he is of his own limitations, subjectivity and indebtedness to it. Typical of Levi, his deferent and unostentatious way points to the fact that scientific research puts nature first and the scientist second.

4. Levi, The Periodic Table, 232.

5. The term 'microhistory', which is used here for the first time autonomously by Primo Levi, is the subject of a comprehensive article authored by Carlo Ginzburg called 'Microhistory: Two or Three Things that I Know about It.' In it, he traces the history of the self defined term back to the American scholar George R. Stewart in 1959. Stewart calls microhistory a particular historical detail that could have changed a historical outcome, but did not. Subsequent 
meanings of the term refer to "local history, written as [Mexican scholar Luis] Gonzalez stressed citing Paul Leuilliot, from a qualitative rather than a quantitative perspective', (p. 12) also in the sense of Nietzsche's 'antiquarian or archaeological history' (p. 12). For Braudel, however, who published an article in the Traité de sociologie edited by Georges Gurvitch (1958 60), 'microhistoire had a precise but negative connotation. It was synonymous with that "history of events" [histoire événementielle], with that "traditional history" that saw the "so called history of the world" dominated by protagonists who resembled orchestra directors', (p. 13) hence 'less interesting' than microsociology, on the one hand, and econometrics on the other (p. 13). Levi's microhistory reverts this slightly negative connotation to mean a particular individual (his)story: 'The reduction of scale suggested by the word microhistory fits in with the acknowledgement of the limits of existence, with the sense of one's own capacities that dominates this passage,' (p. 15) maintains Ginzburg. Levi's vision on microhistory seems to be consistent with the Italian microstoria, whose roots extend to the French tradition of microhistoire, and particularly to Italo Calvino's translation of Raymond Queneau's Les Fleurs Bleues from 1976. Ginzburg also correctly notes that 'the last page of 'Carbon' in The Periodic Table echoes closely the last page of Calvino's Il barone rampante. A fresh encounter between Calvino and Primo Levi, by way of Queneau, occurred a few years later due to the Italian translation of the latter's 'Petite cosmogonie portative' (p. 15). Essential is the fact that after Levi, the term microhistory gained legitimate historical usage.

6. In Sexing the Self, Elspeth Probyn overtakes the concept of 'the geography of the self', which was first used by Michel de Certeau in 1974, and applies it to the gendered, feminine identity: "The work of Michel de Certeau brings to mind the intricacies involved in "doing" the quotidian (both researching it and speaking from it). He reminds us that the questions asked from the everyday can also rearrange its landscape, what he calls a "geography of the possible" (1974). Simply put, there are different ways of getting around and getting by.' Probyn goes on to discuss De Certeau's distinction between the concept of 'strategy' and 'tactic', affirming that because of 'women's historical lack of institutional "loci", one could generalise that their speech is tactical (that is, uttered from a position of marginality) rather than strategic. And that is so because strategy, says De Certeau, is used to manipulate power relations, whereas the tactic is the 'art for the weak'." De Certeau (1984), 35 8, quoted in Probyn (1993), 75.

7. Lejeune, On Autobiography, 4.

8. Ibid.

9. Lejeune as quoted and discussed in Eakin, Touching the Self, 245.

10. Eakin, Touching the Self, 29.

11. Derrida, 'The Law of Genre,' 212, 206.

12. Paul de Man, 'Autobiography as De Facement,' 921, quoted in Anderson, Autobiography, 12.

13. Anderson, Autobiography, 13.

14. Benstock, The Private Self, 11.

15. As discussed by Anderson, Autobiography, 61 .

16. Lacan, The Four Fundamental Concepts of Psycho Analysis, 20.

17. Ibid., 130 .

18. Gusdorf, 'Conditions and Limits of Autobiography,' 35.

19. Ibid.

20. Martin, 'The Quest for the Ultimate Sign,' 225.

21. Levi, The Drowned and the Saved, 24.

22. Gusdorf, 'Conditions and Limits of Autobiography,' 389.

23. Levi, The Periodic Table, 5.

24. Ibid., 23.

25. 'The separation between friends and foes', my translation. Levi, I sommersi e i salvati, 689.

26. Martin, 'The Quest for the Ultimate Sign,' 229.

27. Bradley and Armand, 'Introduction. Thinking Technicity,' 9.

28. For a more detailed enquiry into the nature of techné in Primo Levi's The Periodic Table, see my previously published book chapter on 'Transgressive Legacies of Memory,' 2848.

29. Belpoliti and Gordon, eds., The Voice of Memory: Primo Levi, Interviews, 174.

30. That is, 'the periodic system' (my emphasis) versus the literal equivalent of Mendeleev's table in Italian. 
31. Designates the middle way between excess and deficiency, and points to the ability of the virtuous person to choose the right action.

32. Quote from the 'Introduction' to Nicomachean Ethic, xv.

33. Gordon, Primo Levi's Ordinary Virtues, 134.

34. 'I am an amphibian, a centaur. [... ] I am divided in two halves. One belongs in the laboratory. The other one is in my writing, my response to the interviewers, and in the work on my past and present experience. I am like the two halves of a brain' (translation by the author). Belpoliti and Gordon, Conversazioni e interviste, 7.

35. '[Marx] is not prepared $[\ldots]$ to define the essence of humanness in terms of $[\ldots]$ reason or faith [...] For Marx human beings are not essentially rational creatures, or children of god, or political animals. By contrast, human beings are not essentially anything; they are what they do and what they do is work to derive a life for themselves from the world around them. Everything about them, including their consciousness of themselves and their understanding of nature and their belief in God is a direct product of what they physically do in their daily lives.' Johnston, Lecture on Marx.

36. Laclau, 'Bare Life or Social Indeterminancy,' 14.

37. LaCapra, 'Approaching Limit Events. Siting Agamben,' 1339.

38. The term Muselman (plural Muselmanner) (literally 'the Muslim') originates in the image of Arabs praying and it was coined by Giorgio Agamben to designate the people dying of malnutrition at Auschwitz (Remnants of Auschwitz, 41 87). This image is passingly conveyed in Levi's The Periodic Table in 'Cerium', the only chapter dealing with Levi's internment at Buna Monowitz, Auschwitz. The Muselman is a border figure between man and non man, given his emaciated features and shadow like appearance.

39. Levi, The Periodic Table, 26.

40. In the 'Introduction' to an edited collection of chapters, Joseph Farrell describes Primo Levi as belonging to a generation of austere humanists who believed in the 'cult of reason' and perceived man as 'rational animal'. He mentions R. Gordon's placement of Levi within the 'Enlightenment' current of thought which prioritises such 'ordinary virtues' as 'common sense, a respect for rights, a recognition of the worth of a pursuit of happiness' (in Primo Levi. The Austere Humanist, 9 11), which partially echo the Aristotelian system of virtues as enumerated in his Nicomachean Ethics.

41. Excerpt from his posthumous work The Black Hole of Auschwitz, quoted in Antonello, 'Primo Levi and "man as maker",' 91.

42. Ibid., 989.

43. Tiles, Bachelard: Science and Objectivity, 173.

44. Tiles had previously explained how 'a reading of Boyle, Newton, Priestly or Lavoisier shows just how difficult was the problem of determining chemical compositions and establishing a list of elements' in the absence of a unifying theory that determined the objective identity of such elements in relation to their chemical composition, and not their appearance, taste or combinatory qualities (Tiles, 1723 ).

45. For a riveting account of the classic versus modern connotations of techné in literature, philosophy and politics, see a documentary film by D. Barison and D. Ross entitled The Ister (that is, the ancient name for Europe's greatest waterway, the Danube). In this film, contemporary philosophers (Bernard Stiegler, Jean Luc Nancy, Philippe Lacoue Labarthe and Hans Jürgen Syberberg), along with archaeologists, natural scientists and architects, discuss the concept of techné starting from Heidegger's 1942 Hölderlin lectures and meditate on the nature of war, oppression and genocide. Particularly interesting is the long meditative pause on the significance of techné as technology and its logistic and philosophical implications in the occurrence of the Holocaust.

46. These are for the most part ethnological or allegorical stories that carry an ethical message.

47. Emmett, 'L'uomo salvato dal suo mestiere,' 116.

48. Levi, Moments of Reprieve, vii ix.

49. Levi, The Periodic Table, 160.

50. Antonello, 'Primo Levi and "Man as Maker",' 101.

51. Levi, The Periodic Table, 39.

52. Wilson, 'Narrated Memories,' 98.

53. The racial laws were made public in Italy as the 'Manifesto of Italian Racism' (1938).

54. Levi, The Periodic Table, 7. 
55. Baxter, 'Writing as a Means of Survival,' 398.

56. Levi, The Periodic Table, 145.

57. The centrality of Levi's testimonial gesture to his narrative work exemplifies the Aristotelian virtue of 'voluntariness and responsibility': Levi makes a rational choice to preserve memory and, one may argue, he does so by conferring Auschwitz the central position. His sense of responsibility for the preservation of truth also shows in his choice to narrate a less than laudable act of greed, not a virtue, but a vice.

58. Levi, The Periodic Table, 144.

59. Botez, Transgressive Legacies of Memory, 389.

60. The image of the homo faber as described here is partially consistent with that described by Hannah Arendt (The Human Condition, 80), save he can never be the master of nature and can never denaturalise it: the human being is a maker who 'fabricates the sheer ending variety of things whose sum total constitutes human artifice'.

61. Botez, Transgressive Legacies of Memory, 39.

62. Levi, The Periodic Table, 36.

63. Ibid., 41.

64. Ibid., 45.

65. Ibid., 46.

66. As in the story of the chicken excrements used for producing lady's lipstick in the chapter called 'Nitrogen' (Levi, The Periodic Table, 188).

67. Gordon, Primo Levi's Ordinary Virtues, 139.

68. Ibid., 144.

69. Roth, 'Conversation in Turin,' 56.

70. Ibid., 67.

71. Cerium was used to build flints for cigarette lighters and barter them for food.

72. Levi, The Periodic Table, 146, 150.

73. Gordon, Primo Levi's Ordinary Virtues, 145.

74. Alberto is, in Gordon's view, the modern Prometheus, Levi's protector in the camp (Levi, The Periodic Table, 188 9).

75. 'The insignificant details' (translation by the author).

76. Eagleton, On Evil, 100.

77. Ibid., 101.

78. Levi, The Periodic Table, 233.

79. Antonello, 'Primo Levi and "Man as Maker",' 99.

80. Levi, The Periodic Table, 236.

81. Cf. E. Levinas (Totality and Infinity: An Essay on Exteriority, 43) for an exploration of the other as component of the self.

82. Botez, Transgressive Legacies of Memory, 43.

83. Levinas, Totality and Infinity, 98.

84. Gordon, Primo Levi's Ordinary Virtues, 182.

\section{Notes on contributor}

Catalina Botez is a Doctoral Fellow in English Literature at the University of Constance, Germany. She has studied and pursued research at Yale University, the University of Sydney, Australia and the University of Iasi, Romania. Her work focuses on Trauma and Identity Studies, Holocaust (Post )Memory, Transnationalism, Transculturality and Migration, particularly as reflected in the recent literature of the Holocaust. Her current thesis explores transnational topographies of trauma in contemporary Holocaust fiction, and the way post Holocaust identity is moulded by exposure to diasporic environments in Canada, Europe and Australia. Catalina Botez is the recipient of several international research and travel grants and her work has appeared or is forthcoming in Literature and Aesthetics. The Journal of the Sydney Society of Literature and Aesthetics, Social Alternatives, Philologica Jassyensia (RO), Babilónia: Revista Lusófona de Línguas, Culturas e Tradução and Global Interdisciplinary Research Studies (Inter Disciplinary Network: Oxford, UK), in addition to chapters for several edited volumes by Routledge Taylor \& Francis Group, Intellect Ltd., and Berghahn Publishing (UK). She has also edited a transdisciplinary essay collection on Pluralism, Inclusion and Citizenship. 


\section{Bibliography}

Agamben, Giorgio. Remnants of Auschwitz. The Witness and the Archive Trans. D. Heller Loazen. New York: Zone Books, 1999.

Anderson, Linda. Autobiography. London and New York: Routledge, 2001.

Angier, Carol. The Double Bond: Primo Levi, A Biography. New York: Farrar, Straus and Giroux, 2002.

Antonello, Pierpaolo. "Primo Levi and 'Man as Maker'." In The Cambridge Companion to Primo Levi, edited by Robert S.C. Gordon, 89 103. Cambridge: Cambridge University Press, 2007.

Arendt, Hannah. The Human Condition. Chicago: University of Chicago Press, 1958.

Aristotle. Nicomachean Ethics Trans. and ed. Roger Crisp. Cambridge: Cambridge University Press, 2000.

Bachelard, Gaston. Le matérialisme rationnel. Paris: PUF, 1993.

Barison, David, and Daniel Ross. The Ister Video Digital Betacam. Melbourne: Blackbox Sound and Image, 2004.

Baxter, Jeanette Anne. "Writing as a Means of Survival in the Testimonies of Primo Levi." In The Camp Narratives of Internment and Exclusion, edited by Colman Hogan and Marta Marín Dòmine, 384 402. Newcastle: Cambridge Scholars Publishing, 2007.

Belpoliti, Marco and Robert Gordon, eds. Primo Levi. Conversazioni e interviste, 19631987. Torino: Einaudi, 1997.

The Voice of Memory: Primo Levi, Interviews, 1961 1987. New York: Polity Press, 2001.

Benstock, Shari. The Private Self: Theory and Practice of Women's Autobiographical Writings. London: Routledge, 1988.

Botez, Cătălina. "Transgressive Legacies of Memory: The Concept of Techné in Primo Levi's The Periodic Table." In Integrity and Historical Research, edited by Tony Gibbons and Emily Sutherland, 28 48. New York: Routledge, 2012.

Bradley, A., and Armand, L. eds. 2006. Technicity. Prague: Litteraria Pragensia.

Derrida, Jacques. Memoires for Paul de Man Trans. Cecile Lindsay, Jonathan Culler, Eduardo Cadava, and Peggy Kamuf. New York: Columbia UP, 1986.

Eagleton, Terry. On Evil. New Haven and London: Yale UP, 2010.

Eakin, Paul John. Touching the World. Reference in Autobiography. Princeton: Princeton UP, 1992.

Emmett, Lucie. "L'uomo salvato dal suo mestiere: Aspects of Se questo e un uomo Revisited in Primo Levi's Il sistema periodico." Italian Studies 56 (2001): 11528.

Farrell, Joseph, ed. Primo Levi. The Austere Humanist. Bern: Peter Lang, 2004.

Ginzburg, Carlo. "Microhistory: Two or Three Things that I Know about It." Critical Inquiry 20 (Autumn 1993): 1035.

Gordon, Robert S.C. Primo Levi's Ordinary Virtues. Oxford: Oxford University Press, 2001.

Gusdorf, Georges. "Conditions and Limits of Autobiography." In Autobiography: Essays Theoretical and Critical, edited by James Olney, 28 49. Princeton: Princeton University Press, 1980.

Johnston, Ian. "Lecture on Marx." Vancouver Island University. http://records.viu.ca/ johnstoi/introser/ marx.htm [Accessed 30 March 2012].

Lacan, Jacques. The Four Fundamental Concepts of Psycho Analysis. Harmondsworth: Penguin, 1979.

LaCapra, Dominick. "Approaching Limit Events. Siting Agamben.” In Agamben. Sovereignty \& Life, edited by Matthew Calarco and Steven DeCaroli, 126 63. Stanford: Stanford University Press, 2007.

Laclau, Ernesto. "Bare Life or Social Indeterminancy." In Giorgio Agamben. Sovereignty \& Life, edited by Matthew Calarco and Steven DeCaroli, 11 23. Stanford: Stanford UP, 2007.

Lejeune, Philippe. On Autobiography. Theory and History of Literature Vol. 52. Translated by Katherine Leary. Minneapolis: University of Minnesota Press, 1989.

Levi, Primo. The Drowned and the Saved Trans. Raymond Rosenthal. New York: Summit Books, 1988.

. The Periodic Table Trans. Raymond Rosenthal. New York: Everyman's Library, Alfred A Knopf, 1995.

Moments of Reprieve. A Memoir of Auschwitz Trans. R.D. Feldman, $3^{\text {rd }}$ edition New York: Penguin Books Ltd., 1995.

Levinas, Emmanuel. Totality and Infinity: An Essay on Exteriority Trans. Alfonso Lingis. Pittsburgh: Duquesne University Press, 1969. 
Martin, Stephen. "The Quest for the Ultimate Sign: Binaries, Triads and Matter in Primo Levi's $I l$ sistema periodico." Romance Languages Annual: RLA/ Purdue Research Foundation 8 (1996): 22531.

Probyn, Elspeth. Sexing the Self. Gendered Positions in Cultural Studies. New York: Routledge, 1993.

Roth, Philip. "Conversation in Turin with Primo Levi." In Shop Talk. A Writer and His Colleagues and Their Work, edited by Philip Roth, 1 18. London: Jonathan Cape, 2001.

Tiles, Mary. Bachelard: Science and Objectivity. Cambridge: Cambridge University Press, 1984.

Wilson, Rita. "Narrated Memories: the Writings of Primo Levi." Acta Germanica: German Studies in Africa; Jahrbuch des Germanistenverbandes im Sudlichen Afrika 23 (1995): 93106. 